\begin{tabular}{|c|}
\hline $\begin{array}{c}\text { ASIAN SOCIAL WORK } \\
\text { JOURAL } \\
\text { (ASW) }\end{array}$ \\
Volume 1, Issue 1, May 2016 \\
Journal home page: \\
www.msocialwork.com \\
\hline
\end{tabular}

\title{
Changes in the Dimensions of Life of Filipino Deportees from Malaysia
}

\author{
Prof. Dr. Bagian Aleyssa A. Abdulkarim ${ }^{1}$ \\ ${ }^{1}$ Western Mindanao State University, Zamboanga City Philippines \\ Corrrespondence: Prof. Dr. Bagian Aleyssa A. Abdulkarim
}

\begin{abstract}
This research examined the life experiences of Filipinos deported from Malaysia. Anchored on the symbolic interaction theory, the study sought to investigate how the interpretation of these experiences defined and shaped their personhood. It documented the life experiences of Filipino deportees before and after deportation from Malaysia to determine the consequences of such forcible repatriation on their health, socio-economic, cultural and psychosocial dimensions of life. The study looked into coping strategies with life changes focusing on deportation as a main turning point and identified this event's differential treatment considering the variables of age and sex group. The research utilized a exploratory design and presented extensive case studies of 24 Filipino deportees, eight of which are included in this paper synthesized from in-depth interviews of deportees and key informants. Other technique used were non-participant observation and data gathering from records of government offices assisting the repatriates including the Department of Social Welfare and Development Region 9 and the Zamboanga City Philippines Social Welfare and Development Office. The study showed varying consequences of deportation with respect to the deportees' health, socio-economic, cultural, and psychosocial condition. While all the respondents admitted having been adversely affected by their deportation there is evidence of remarkable resiliency and optimism as gleaned from their narrations. Deportees have varied interpretations of deportation in their lives. For some respondents, the experience meant re-connection and re-union with the family in the place of origin. For others, the experience meant free travel to their homeland. A number of respondents reported deportation was an opportunity to be free from detention, an experience which they described as "hell". Most of the deportees were stigmatized with the new identity, that of a Halau. Deportation was a shameful event to the family and friends but it has to be accepted because it happened and they made it happened. The respondents interpreted experience as evidence they were "meant to be at the lower rung of the ladder of life due to many reasons. Many reported the deportation experience meant they lost loved ones and felt diminished in individual worth and dignity. The recommendations that the study can make have been elucidated in the findings of the study which can be realize through policy formulation, advocacy, education/information, social networking and social services.
\end{abstract}

Key words: migration, deportation, Filipinos, chain migration, pul1/push factors

\section{Introduction}

Residential dislocation appears to be in the order of the day especially in instances where local resources that are deemed for use only by legitimate citizens are threatened by the presence of persons 
who are defined as outsiders. Internally, residential dislocation takes the form of forced relocations or eviction within the country in the case of squatters or informal settlers. Across state borders, it takes the form of deportation. The forced relocation of informal settlers has one set of stories. Deportation has another set.

The deportation of Filipinos from Malaysia is of interest for this study as the researcher has personally seen thousands of families arriving in Zamboanga City. The gravity of this problem may be gauged from a report that there are about half a million undocumented Filipinos in Malaysia, some 100,000 of whom have already been deported back to the Philippines. The rest are in prison camps in Sabah and Sarawak or in hiding (Cabaraban \& Fernandez, 2005:2).

What people read in the newspapers, hear from broadcast media outlets, or examine in official service statistics are numbers without faces, or some generalized description of the plight of the deportees. Much is unknown about how they lived, survived or coped with difficulties, how they see events as they unfolded, or what was in their minds as they were undergoing these experiences. In addition to these unknowns, practically nothing is known about their points of view that may have some implications on their life in the future, or provide clues as to what they might do in response to this event. For example, after people have left for Malaysia and settled there, they may have felt they do not belong to the Philippines anymore, and that Malaysia was their home, providing them with the opportunities to earn income, express their beliefs in religious festivities with the local people and enjoy the security of living in a country that has been gaining momentum for economic take-off. And yet, they have been defined by Malaysian authorities as "outsiders," that was why they were deported. Defined as such, how do they in turn define themselves now? How do they view the future for themselves and their children? Are they resigned to this fate? Do they share common identities and interests with other deportees? Issues on life circumstances, coping strategies, future outlook, and definition of identities of deportees can have serious implications on human welfare, peace and stability in the southern Philippines and elsewhere.

Deportation of Filipinos from Malaysia is not a recent phenomenon. Many Filipinos from the southern islands especially the Tausog, Sama and Badjao (Sama dilaut) have been coming in and out of Malaysia particularly in Sabah. The Department of Social Welfare and Development (DSWD) Field Office IX in Zamboanga City (2008) started to receive and serve deportees from Sabah, Malaysia as early as 1986. Based on a report by this agency in 2008, 83,498 deportees were served from 1995 to 2008; the majority of these (88.9 percent) came from the Autonomous Region of Muslim Mindanao (ARMM), specifically from Basilan, Sulu and Tawi-Tawi, while the rest came from other parts of the country.

The Filipino undocumented migrants deported from Malaysia are called halau, a Malay word, which literally means "to cast out, to eject, to throw away." It also means "to drive away someone from the house;" or, "to get rid of someone in an insulting manner." Another meaning is the one commonly understood by the Tausog. It refers mostly to Filipino immigrants in Sabah, Malaysia who are deported to the Philippines by Malaysian authorities in what some have described as disgraceful manner. As such, the term further connotes that these people were found to have violated Malaysia's law on migration. More specifically, thus, halau refers to undocumented Filipino migrants expelled forcibly from Malaysia. The word therefore, carries a meaning which is shameful, causing dishonor as it hurts the personal dignity and pride of the person driven away. The Filipino deportees might have been fittingly called thus considering the enforced means of removal they were made to undergo from an inhospitable country (Jikillulla, 2005:12).

For many Filipinos living in the South, specifically those from Sulu and Tawi-Tawi, Sabah has become a second home. In search of work they desperately need but find unavailable in the Philippines, they risk going back and forth to Malaysia for job opportunities. But though jobs are available, the migrants encounter difficulties in Malaysia. They become vulnerable to exploitation and discrimination due to their illegal status. Non-payment of wages and unexplained deductions are examples of exploitation experienced by male workers. Among women workers, "experiences of sexual harassment occurred 
mostly at the workplaces such as karaoke bars, restaurant and bakeries" (Cabaraban \& Fernandez, 2005).

Migrante International's Fact Finding Mission concluded that Malaysia's crackdown of 2002 was abusive, dreadful and inhuman. Undocumented migrants were arrested from their houses, in their workplaces and even in public places. In the detention centers, 200 to 500 deportees were crammed in one cell. They were made to sleep on the floor, made of either wood or cement without mattress. Children and adults who got sick while inside detention cells did not receive any medical attention or treatment (Migrante International, 2008).

Researchers pointed out that deportation has its effect on health, livelihood and family structure. (Cabaraban \& Fernandez, 2005; Dans, 2000: Jikillulla, 2005). The long-standing threat of expulsion the coercive manner of rounding up, the congestion and unhygienic condition in the jail exacerbated the health risk of deportees especially children. While the loss of a job is a painful experience, separation of family members from one another as wives separated from husbands or parents from their children may possibly be more traumatic.

All these realities experienced by the Filipino deportees, as gleaned from the several sources including research and other types of studies/ literatures available, motivated this researcher to conduct further studies on the plight of the Filipino deportees from Malaysia before and after deportation. Reports from the Department of Social Welfare and Development Region 9 show that thousands of Filipinos were deported but there was no research conducted on the socio-economic, cultural and psychosocial conditions of the deportees after the deportation. Having personally seen and heard the voices of the deportees relating their traumatic experiences when they were in Malaysia and the uncertainty of life and seemingly bleak future that lies ahead of them challenged the researcher to pursue this study that would eventually serve as basis for the full implementation of the reintegration program of the line agencies concerned with deportees.

\section{Theoretical Framework}

If men define situations as real, they are real in their consequences, - W.I. Thomas (1965:301 in Maciones, 2006:145)

This famous theorem posits that reality is defined by the human person and action or behavior is made on the basis of such a definition. The researcher utilized Symbolic Interaction Theory as the major theoretical framework to understand the biological, socio-economic, cultural and psychosocial conditions of deportees before, during and after deportation. It is anchored on symbolic interaction because the study aims to investigate how the deportees interpret these experiences and how they define themselves after these experiences. The basic tenets of symbolic interaction are as follows:

1. people learn the meanings and the symbols that allow them to exercise their distinctively human capacity for thought;

2. meanings and symbols allow people to carry on distinctively human action and interaction; and

3. people are able to modify or alter the meanings and symbols that they use in action and interaction on the basis of their interpretation of the situation (Ritzer, 2000).

Symbolic Interaction researchers investigate how people create meaning in their social interactions; how they present and construct " the self or identity" and how they define situations of being in copresence with others. One of the perspective's central ideas is that people act as they do as a result of how they define their situations.

According to Turner (1982), the Symbolic Interaction Theory is a framework used for building a theory that sees society as the By-product of the everyday interactions of individuals. In the social interactions that happen in everyday life, society is nothing more than the "shared reality" that people construct as they interact with one another. Human beings live in a world of symbols wherein meanings are attached to virtually everything. Preliminary to any self-determined act of behavior, there 
is always a stage of examination and deliberation which may be called the "definition of the situation". And actually, not only concrete acts are dependent on the definition of the situation, but gradually, a whole life-policy and the personality of the individual himself follows from a series of such definitions. Thomas and Thomas (1928) observed that most of the definitions of situation have been provided for by society. They emphasize this point identifying especially the family and the community as sources of the social definitions. However, their position is distinctive for its emphasis on the possibility of spontaneous individual definitions of situations, which allow people to alter and modify meaning and symbols.

An interpretation of the migrant situation according to symbolic interaction would state that the migrants must have defined a situation of helplessness and stagnation in the Philippines. Additionally, they must have defined Malaysia then as laden with opportunities for advancement. Acting on these definitions, they decided to move. Whether these definitions fit reality is a peripheral issue; the fact was they defined these as realities and acted on them accordingly.

When the migrants left the country of origin, they must have some definitions of their biological (health), socio-economic, cultural and psychosocial life that made them feel capable of going on such a venture. After settling for years in Malaysia, they must have made some adjustments in the various dimensions of their lives. These are assumptions about conditions in the more distant past. In the recent past, however, a major turning point has occurred in their lives, a turning point that defined realities for them - their deportation. This then, is the focus of the study. How has this turning point affected the various dimensions of and the functioning of these dimensions in their lives? Did deportation have differential effects on persons of the various age categories, and of different sex groups in terms of the deportee's health conditions? Does deportation have more debilitating effects on women and children than men and adults thus making them a special group? What socio-economic and cultural dislocations were occasioned by the deportation? What psychosocial effects does deportation have on the deportees? How do they accept the events in their lives? These and other questions will be addressed in the study as shown in Figure 1

Figure 1 : Schematic Diagram of the Framework of Analysis

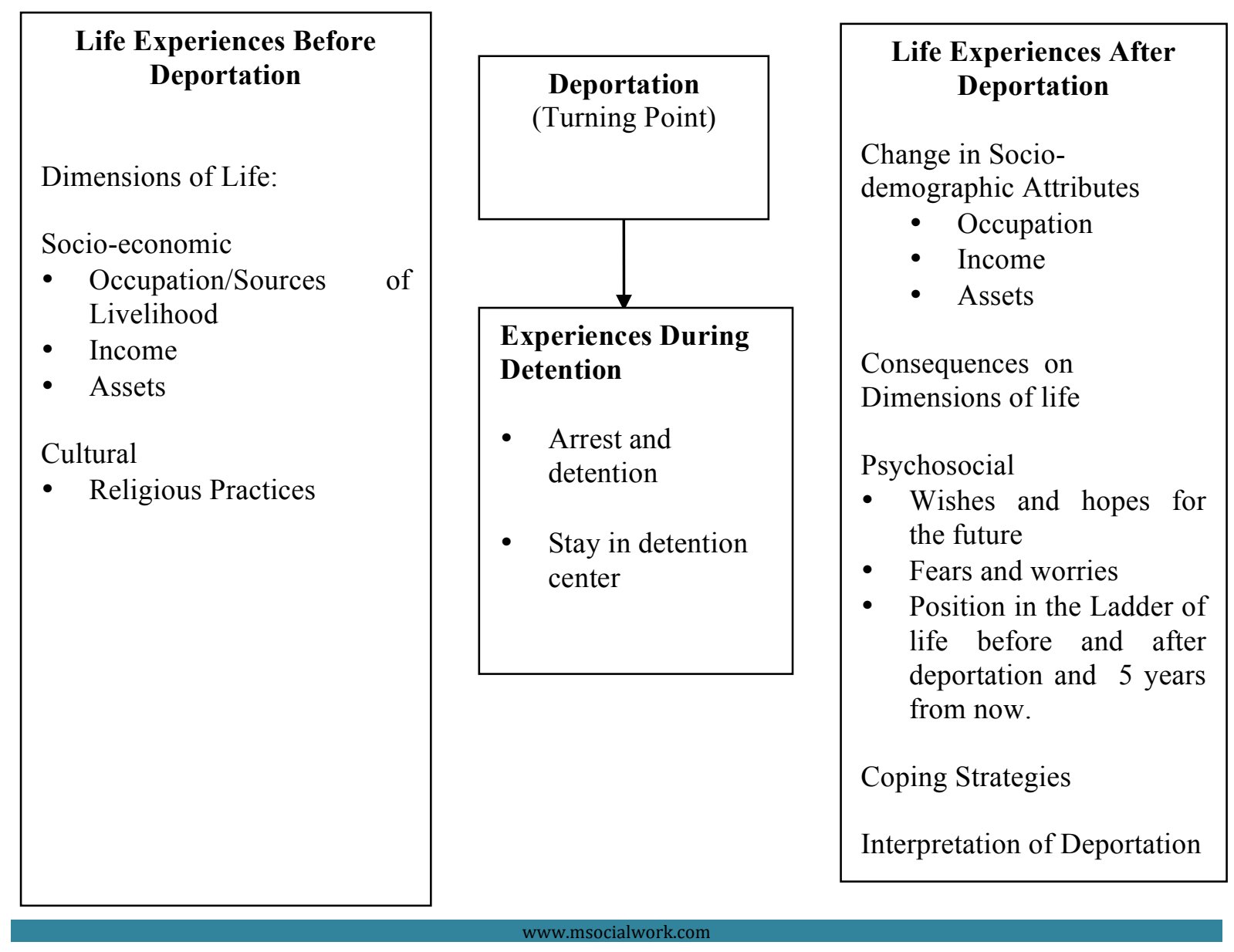


The dimensions of life of the deportees investigated in the study were adapted from an American anthropologist named Mandelbaum's (1973) view of a person's life history. A dimension of a person's life is made up of experiences that stem from a similar base and are linked in their effects on the person's subsequent actions. For analytical purposes, these experiences are classified into biological (health), socio-economic, cultural and psychosocial dimensions. In reality, they intertwine and interact in many ways. Accordingly, this would have been psycho-reductionism if not for the social dimensions that impinge upon the individual behavior.

The biological dimension refers to differences age and sex of the deportees that may occasion the differential effect of the deportation in terms of physical well-being. The physical well-being assumes the ability to function normally in activities such as bathing, dressing, eating, and moving around. The cultural dimension lies in the mutual expectations, understandings, and behavior patterns held by the people among whom a person grows up and in whose society s/he becomes a participant. Behavior patterns include relations to religious practices, festivities /celebrations. The socio-economic dimension of person's life refers to the social and economic well-being of the person. Social wellbeing relates to one's ability to participate in society, fulfilling the roles as family member, friend, worker, or citizen or in other ways engaging in interactions with others. The economic dimension of person includes the occupation or the sources of livelihood, investments, savings and assets.

The psychosocial dimension focuses on the individual's subjective world, on his/her general feelings and attitudes. In this study, it is worth investigating the deportees' wishes and hopes for the future; fears and worries. The study included an assessment of the position in the ladder of life before and after deportation.

Mandelbaum (1973) viewed the turning points as the major transitions that occur as the person takes on a new set of roles, enters into fresh relations with a new set of people, and acquires a new selfconception. In this study, deportation is considered the major turning point of the Filipino deportees. Biologically, the turning points would be puberty, getting sick and coming of age. Working for money, coming of age and getting married for socio-economic turnings. Interpretations of events in society that impinge upon the individual and how these events affect him (biologically, economically, culturally) a person's view of his prospects of influencing social and community events and participating in organizations are possible turning points for the cultural dimension. The individual's view of interplay between history and biography are likewise possible turnings for the psychosocial dimension.

A life history involves an on-going development in various spheres of behavior; it includes continuous adjustment and periodic adaptation. Mandelbaum (1973) defined adaptation as the changes that have major effects on a person's life and on his basic relationships with others, a behavior that contributes to the survival of the individual or the group. Meanwhile, Bennett (1996:3) described adaptation as "distinctive features of human behavior that underlie the human relationships to the environment - in particular, the remarkable plasticity of response and the ability to solve problems arising from such responses. " Elaborating further, Bennett adds that what maybe adaptive to the individual may be maladaptive for the group. Thus, value judgment influences the coping behavior or adaptation of humans. In view of this, he opined that it is important not to neglect the value dimension since doing so leads to a neglect of the anticipatory aspect of behavior. While human behavior allows for a wide range of responses due to the element of freedom, the majority of coping mechanisms are based on precedents. Bennett (1996:29) further stressed that "the values used to assess the consequences of adaptation are almost always derived from the mind-sets established before the particular adaptive events" Moreover, according to this author, human adaptive behaviors characterized not merely by symbol generation (that is culture) but also memory storage (learning) and the preservation of out model (perceptually maladaptive) solutions that generate conflict.

In his study, it focuses on the biological dimensions which includes the health of the deportees as well as the socio-economic, cultural and psychosocial dimensions of life.

Coping is a way of adjusting (McConnel, 1989 cited in Gille, 2002:6); it is also the capacity to respond to, and to recover from stressful events. Vulnerability and capacity to cope are opposite facets of the 
same complex. This complex is made of factors and stresses that can be: 1) infrastructural like biological, demographic and environmental; 2) structural that includes social and economical; and, 3) super structural like cultural and political. The concept of coping mechanisms and or strategies is closely related to the idea of survival and threat. The coping strategies vary by region, community, social groups, household, gender, age, season and time in history. They are deeply influenced by the people's previous experience. Adopting this theory to the current study, it is posited that the values and historical memory of Filipino deportees in relation to their deportation are possible factors of their acceptance of the event in their lives.

\section{Statement of the Problem}

This research investigated the life experiences of Filipino deportees before and after deportation from Malaysia. Moreover, the study sought to determine the effects of deportation to the health, socioeconomic, cultural and psychosocial dimensions of life and document the deportees coping strategies after having been deported.

Specifically, the research sought to answer the following questions:

1. What are the life experiences of deportees before and after deportation from Malaysia?

2. What are the consequences of deportation with respect to the deportees'
a. health condition
b. socio-economic condition
c. cultural condition
d. psychosocial condition

\section{Objectives of the Study}

The general objective of the research is to investigate the life experiences of the Filipino deportees before and after deportation from Malaysia. Specifically, the research investigates how deportation operates as a turning point that alters the health, socio-economic, cultural and psychosocial dimensions of life and the coping strategies with the exigencies of life after having been deported.

Specifically, the objectives of the study are the following:

1. To identify and describe the life experiences of the deportees before and after deportation from Malaysia;

2. To find out the consequences of deportation on the health, socio-economic, cultural and psychosocial dimensions of life of the deportees.

\section{Methodology}

This is an exploratory research of the life experiences of the Filipino deportees before and after deportation. It tried to explain the effects of deportation with respect to socio-economic, cultural and psychosocial dimensions of life of the deportees; the coping mechanisms with life's changes after deportation; the interpretation of the major events in their lives and the differential effects of deportation on various age and sex groups in terms of health, socio-economic cultural and psychosocial dimension of their lives.

It is the thesis of this study in social interaction that people learn the meaning and the symbols that allow them to exercise their distinctively human capacity for thought. Meanings and symbols allow people to carry on distinctively human action and interaction and people are able to modify or alter the meanings and symbols that they use in action and interaction on the basis of their interpretation. 
To determine the respondents, a purposive sampling was used. Twenty four Filipino deportees were chosen based on the criteria set for respondents: age of respondents was categorized into three: below $18,18-40$ and 41 above; sex into male and female and waves of deportation from 2002 to 2004 and 2005 to 2008 and 2008-2011. Eight of the twenty-four respondents were taken as case studies.

Primary and secondary sources of data were utilized. In-depth interview of the Filipino deportees and key informants were done using an In-depth Interview Guide. Data from the Department of Social Welfare and Development and City Social Welfare and Development Office in Zamboanga City served as the secondary data in this study.

\section{Research Finding and Discussin}

The findings of the study highlights the following:

\section{Socio-economic and demographic attributes of the respondents}

- The average age is 32 for the deportees and 47 for the service providers.

- Islam is the religion of the great majority of respondents.

- As to ethnicity, most belong to the Sama and Tausog tribe.

- One half of the deportees were married. The average number of children is two and the average number of household member is 6 .

- Deportees are either unschooled or less educated; a great majority reached elementary education level only while all the service providers are college degree holders.

- The occupation of deportees before deportation were in construction, trading, food service, and laborers in the plantation. Women worked as domestic helper and as waitress, dish washer in food service while the men were in construction, fishing, trading, and agricultural work.

- After deportation, almost half of the respondents are unemployed The men with work are engaged in construction work, vending, cook and laborer while the women are in laundry service and in informal work as vending.

- Before deportation the average daily income in Malaysia is RM26 which is equivalent to P338. After deportation those Filipino deportees who were employed earned P125.51 a day. The average daily before deportation was higher than the income after deportation.

- The average length of stay in Malaysia was 12 years.

- The average length of stay in detention center was 76 days or two months and 16 days.

\section{Life Experiences of the Filipino deportees before and after deportation.}

\section{Life Experience of the Filipino Deportees before deportation}

The condition of the places of origin in terms of job occupation, peace and order and relationship with family was characterized as peaceful and without job opportunities. If there are, then it is in fishing, farming which earns a meager income.

The reasons to migrate is brought about by a confluence of the following factors and events:

- Economic reasons;

- Life in the places of origin is difficult due to absence of job opportunities and was affected by both armed conflict and family feud (rido);

- Escape from political persecution, marital conflict and avoidance of worsening peace and order conditions;

- The desire to find work and earn more; 
- To join the families and relatives who exaggerated 'success stories' of good life in Malaysia.

The reason to migrate and find work despite illegal status was a behavior influenced by the symbols they got from the success stories of "significant others" who have good and comfortable life as interpreted by the consumables good existing in the household like appliances, food on the table, clothes, cell phone and other semi-luxurious things.

Chain migration was very evident among the deportees. A great number were brought to Malaysia by either their parents, relatives and friends. These persons assisted them in finding jobs and temporary shelter was shared to them.

Most of the deportees went to Malaysia via the backdoor. For those migrants coming from Palawan, the entry point is from Balabak Island to Kudat, Kuta Kinabalu. From Tawi tawi, common entry point is from Bongao to Felda and Lahad Datu or direct to Sandakan; Sitangkai to Semporna; Taganak, Turtle Island and Mapun, Tawitawi to Sandakan, Malaysia.

The travel time from Southern Philippines to Malaysia ranged from one hour to 24 hours depending on the kind of transportation used.

Most of the deportees who sailed to Malaysia through the back door used four modes of transportation: by temper, a roofless wooden motorized canoe bigger and more elongated in shape which is smaller than the kumpit from Bongao to Sabah, Malaysia; by jungkong - a fuso-engined small boat, roofless without outrigger, longer and wider in size without; tampasak ( malayu term for fishing) boat, and a speedboat.

Most of those migrants going to Malaysia by backdoor had no legal paper like passport while those who took the Zamboanga route to Malaysia by the shipping lines exits with passport stamped by the Bureau of Immigration.

Majority of the deportees migrated to Malaysia without legal documents: passport and working visa. All of the deportees has no birth certificate which is considered as the most important requirement for securing passport.

\section{Life Experiences While In Malaysia}

The length of stay of migrants in Malaysia varies from one person to another. The shortest stay was a day while the longest was 35 years. The mean was 12 years.

While in Malaysia, most of the deportees stayed with parents, relatives and friends. Majority of the deportees found their first work for wages after a month. The earliest time to find the first job was a week after arrival and the longest was two years.

The work was found through the assistance of their relatives and friends who were working there ahead of them. Majority worked without permit. Acquisition of legal papers was considered desirable but impediments were insurmountable: lack of money was the common reason to secure for birth certificate which is a requirements for passporting. Those with expired passport had the habit of procrastination by putting off renewal of expired papers. A considerable number of deportees reported to have employees who were understanding, honest and fair in treating workers. Communication in Bahasa Malaysia and Tausog or Sama is an essential factor in a smooth relationship with the local people and the compatriots the deportees worked with.

While in Malaysia, the deportees identified practices and acts which were interpreted by them as violative of human rights: destruction of dwelling like burning and demolition of houses; exclusion on the availment of social and health services on the basis of inability to present legal papers; children 
born in Malaysia of undocumented parents cannot be registered at birth nor can they go to public school.

\section{Arrest and Detention}

The major reason for the arrest and detention of the migrants was their illegal status due to absence of: passport and identity card and no work permit.

Most of the deportees were caught with expired legal document which were not renewed due to (a) financial and time constraints, and (b) procrastination; and (c) taking things for granted since many of them are similarly situated.

All the deportees were aware of the penalty for illegal migrants: incarceration for months to heavy fine and caning (rotan).

Most deportees were aware of their illegal status as well as the risks of illegal entry from relatives and friends or from announcement made and circulated through television, radio and newspapers. Being aware of the immigration policy of Malaysian government towards illegal migrants, deportees have many ways of evasion from being caught by law-enforcers: transferring from one house to the other, staying in the farm, on the banca hiding in the mangroves, padlocking their houses or room doors; hiding and running from the law-enforcers. There were also those who bribed the law-enforcers.

Incidents of apprehension happened in their houses during unholy hours (1:00 to 3:00 o' clock in the morning), in the workplace, in checkpoints, while doing errand, shopping at the mall and market or while going on a leisurely walk downtown.

\section{Life Experiences During detention}

Most of the deportees after interrogation who were guilty of violation of immigration laws at the police station were incarcerated for a month or two after which they were transferred to a detention center they called Rumah Merah (Red House) in Sandakan, Menggatal Temporary Detention and Kuta Belud Paradise Camp in Kuta Kinabalu.

Men were detained separately from women and children. In the case of family detained with children, the children regardless of sex stayed with the women (mother).

The type of torture that were experienced or witnessed include mauling, beating, exposure to the sun the whole day, kicking forcefully, verbal abuse and threats and other forms of brutality like caning. The effect of torture include disability and death due to mauling and caning; insanity due to severe punishment and maltreatment inside the detention center; scars and crippled lower extremity due to caning and low self-esteem due to verbal abuse.

Problem regarding the conditions in immigration detention center include overcrowding, poor hygiene and sanitation and inadequate nutrition. All these 'inhuman' conditions in the detention center contributed to the ill-health of detainees.

Detainees were deprived of adequate food, water and sanitary environment while in detention center. Deportees held in detention center were often not provided with basic provisions such as tooth brush/paste, bath or washing soap and face towels. However, medicines for minor illnesses were provided when requested.

Visits were allowed on a very limited time. Visitors with no legal papers are not allowed to see detained relatives and loved ones. Items brought were confiscated. Sometimes food brought for the 
detainees were eaten by the guards. Bribery is a common occurrence: the visitors bribed the guard to deliver things for the detainees.

Length of stay in jail varied from person to person, from several weeks to three months to even years for those caught for some criminal acts and had no legal papers. In this study, the average length of detention is 76 days or two and a half months. Detainees reported to keep on following up with the jail guard the status of the detention. Feeling of restlessness, homesickness and uncertainty were experienced by the Filipino deportees while in detention center.

\section{Life Experiences during deportation}

The typology of deportees includes: Filipino migrants who are of illegal status due to illegal entry and stay or illegal alien or Kolorum; children of undocumented migrants whom they called as stateless children; victims of human trafficking and illegal recruitment.

\section{The Effects of deportation to the biological (health), socio-economic, cultural and psychosocial conditions of the deportees.}

\section{Health}

The long standing threat of expulsion, coercive manner of rounding up, inhuman treatment, the congestion and unhygienic condition in jail exacerbated the health risks of deportees especially the women and children.

A married women with three children developed nervousness and was diagnosed to have heart illness. Limited food and water, unhygienic condition as well as limited use of comfort rooms in the detention cells and congestion resulted to cases of malnutrition, dehydration, diarrhea, mild and severe respiratory tract (pneumonia, measles) skin diseases and gastro-intestinal diseases.

Cases of mental disorder/psychiatric problem and crippled, paralyzed due to physical abuse while in detention

Cases of children deaths due to complications were documented by the social workers in the center.

\section{Socio-economic}

Forced separation of family members from one another. Children separated from parents; husband separated from wife and their children. Loss of job and income Affects the fulfillment of the roles of the bread earner of the family. Deportation cut-off the migrants economic activity. Some workers apprehended at the workplace were unable to collect their pay.

\section{Psychosocial}

Hopes and Wishes for the future of the Deportees

- Return and work in Malaysia with legal documents

- Education of the children

- A stable job here

- Own family

- Family solidarity

- Peace (work and family are together)

- Capital for a business

Hopes and Wishes for the future of the Deportees by the Key Informants 
- Provision of a resettlement project for the deportees with components on economic, health, education, shelter and access to social services.

- Institutionalization of the One-Stop Processing Center (OSPC) with funds and personnel.

- A long term plan for the resettlement of Filipino deportees and other displaced families made by the DSWD and other line agencies.

- Amnesty from the Malaysian government to all illegal migrants and workers and absorption as a citizen to the working force.

Fears and Worries of the Deportees

- See their family suffers due to hunger, homelessness and unemployment

- Leaving children without means of livelihood.

- Becoming sick that may results to inability to work and no income to support family;

- Not finishing school.

- Inability to return to Malaysia to see family members and collect belongings

- Loss of family and family separation

Fears and Worries of the Key Informants for the deportees

- Of deportees going to Malaysia without legal documents through the backdoor

- For the deportees not to find a stable job here.

\section{Ladder of Life of Deportees before and after deportation and five years from now}

\section{Before deportation}

The ladder position before deportation refers to the life of the deportees while in Malaysia in terms of work, arrest and detention.

Almost all of the deportees thought to be situated on the fifth to eight rung of the ladder of life before deportation on the following reasons: work with income and family solidarity.

\section{After Deportation}

Majority of the respondents perceived to be on the lower rung of the ladder of life due to no stable job or no means of livelihood at all, family separation, communication and adaptation problem. Communication problem refers to the deportees who were born in Malaysia and the only language they understand is Bahasa Malayu and tausog for dialect.

To a few who thought that they were on the upper rung $\left(6^{\text {th }}\right.$ to $\left.8^{\text {th }}\right)$ of the ladder of life gave these reasons: family reunion in the place of origin and free travel from Malaysia to Zamboanga and livelihood training with the reintegration program of the government.

\section{Five years from now}

- Family solidarity, education, stable job and return to Malaysia with an Identity Card and working visa were reasons for the majority of the respondents to be on the higher rung $\left(6^{\text {th }}\right.$ to $10^{\text {th }}$ ) of the ladder of life.

\section{Recommendations}

Given the findings on the life experiences of the deportees before and after deportation and its effects on their health, socioeconomic, cultural and psychosocial dimensions of life, the following 
recommendations may be offered to the affected group of people: the deportees; the governments of Malaysia and Philippines, the service providers, the community leaders and the academe.

1. Full implementation of Presidential Order 116 directing 14 national line agencies for the integrated delivery of basic services for the deportees where all agency has to enroll them for capacity building, capital assistance, skills training, open employment with capital or employment locally or internationally.

2. To expand the reintegration program of the government led by the Department of Labor and Employment and Technical (TESDA) to other communities especially in the Autonomous Region in Muslim Mindanao for the deportees and other displaced persons. A big bulk of deportees came from the ARMM region.

3. The government to provide a resettlement area that includes the following components: economic provision, health, education, shelter and access to services. Economic provision shall include livelihood training, capital for self-employment and work.

4. A strict regulation of labor recruitment as well as the implementation of the Anti-trafficking law of the Philippine government. Popularizing the laws on labor and migration at the grassroots level to enhance the people's awareness on the issues affecting their lives.

\section{References}

Battistella, Graciano, Maruja Asis, \& Carmen Abubakar. (1997). Migration from the Philippines to Malaysia: An exploratory Study. Commissioned by International Organization for Migration.

Bennett, John W.1996. Human Ecology as Human Behavior: Essays in Environmental and Development Anthropology. Transaction Publisher. New Jersey USA.

Blumer, Herbert .1962 . "Society as Symbolic Interaction", in Arnold M. Rose: Human Behavior and Social Process: An Interactionist Approach. Houghton-Mifflin.

Blumer, Herbert. 1969. Symbolic Interactionism: Perspective and Method. Berkeley: University of California Press. USA

Burke, Peter J. 1980. The Self. Measurement Implications from a Symbolic Interactionist Perspective. Social Psychology Quarterly 43. USA.

Burke, Peter J. et al. 2003. A Sociological Approach to Self and Identity. Washington State University. Gilford Press. USA

Cabaraban, Magdalena C. and Ederlina M. Fernandez. 2005. Halaw The Travails of Filipino Deportees from Malaysia. Davao City: Mindanao Working Group on Reproductive Health Gender and Sexuality.

Dans, S.A. 1999. Filipino Halaws from Sabah, Malaysia: Pre-Migration, Migration, Deportation and Repatriation Status. Zamboanga A.E. Colleges, Zamboanga City

Darwin, Muhadjir, Anna Marie Wattie and Susi Eja Yuarsi . 2003. Living on the Edges: Cross- Border Mobility and Sexual Exploitation in Greater Southeast Asia Sub-region. Gadjah Mada University, Indonesia.

Department of Social Welfare and Development 2000 Annual Report. Region 9. Zamboanga City Philippines.

Fabian, Ma. Luisa D. 2004. Case Study of Zamboanga City (Forced Migration Area). Philippine Institute for Development Studies Discussion Paper Series No. 2004-50. Makati City.

Garcia, Edmundo. 1990. Human Rights Reader: Towards a Just and Humane Society. National Book Store, Inc. Quezon City. Philippines.

Gille, Evelyn A.2000. Coping Strategies of Problems of Selected Parolees of Cagayan de Oro. Xavier University. Cagayan de Oro City.

Good, Carter V and Douglas E. Scates. 1972. Methods of Research Educational, Psychological, Sociological. Appleton-Century-Crofts Educational Division Meredith Corporation. New York.

Hepworth, Dean H. and Jo Ann I. Larsen. 1990. Direct Social Work Practice. Dorsey Press. California, USA.

Hilsdon, Anne-Marie 2006. Migration and Human Rights: the Case of Filipino Muslim Women in Sabah, Malaysia. Women's Studies International Forum 29. Elsevier Ltd, Australia. 
Jalillula, Amilhusin Sabdani. 2005. Halaw Experience: Economic Challenges and Survival of Selected Filipino Deportees from Malaysia. Institute of Islamic Studies. University of the Philippines Quezon City Philippines.

Kanapathy, Vijayakumari 2006. "Migrant Workers in Malaysia: An Overview'. Country paper prepared for the Workshop on an East Asian Cooperation Framework for Migrant Labour,. Kuala Lumpur, Malaysia.

Kanapathy, Vijayakumari. 2004. International Migration and Labour Market Development in Asia: Economic Recovery, The Labour Market and Migrant Workers in Malaysia. Paper Prepared for the 2004 Workshop on International Migration and Labour Markets in Asia. International Labor Office. Malaysia,

Kaur, Amarjit. 2007. Refugees and Refugee Policy in Malaysia. UNEAC Asia Paper No.18. Australia.

Lee, Everett R. 1966 “A Theory of Migration.” Demograhy 3, No.1

Maciones, John.2006. Sociology. $9^{\text {th }}$ Edition. Pearson Prentice Hall. USA.

Mak, J.N. 2006 .Whose Security? Refugees, Illegal Migrants and the Politics of Malay Dominance in Malaysia.

Malaysia. http//www.refugees.org/countryreports.aspx?subm=\&ssm=\&cid=1595 )

Mandelbaum, David G. 1973.The Study of Life History: Gandhi. Current Anthropology, Vol 14, No. 3. Wenner-Gren Foundation for Anthropological Research. USA.

Matsuoka-Jon K. 1985. Vietnamese in America: An analysis of Adaptational Patterns. University of Michigan, USA.

Mc. Connel, James V. 1989 Understanding Human Behavior, $6^{\text {th }}$ ed. In Eveyln A. Gille. 2002. Coping Strategies to Problems of Selected Parolees of Cagayan de Oro City. Unpublished Thesis. Xavier University-Ateneo de Cagayan, Cagayan de Oro City.

Mills, C. Wright. 1969. The Sociological Imagination. London: Oxford University Press.

Naces, Lovenia P. 1990. Child Labor in Cagayan De Oro City: An Exploratory Study. Xavier University Cagayan de Oro City.

Pava, Herminio, Isabelo Mugot, Jesus Manubag, Jose Arances, Josefino Magallanes and Isaias S. Sealza. 1992 Bukidnon Upland Development Studies.: Volume 2, Bukidnon:Central Mindanao University.

Plummer, Kenneth. 1975. Sexual Stigma: An Interactionist Account. Routledge \& Kegan Paul.London.

Rajendran, Shobhana, David Veronesi, Nasrudin Mohammad and Alimudin Mala. 2006. The Impact of Armed Conflict on Male Youth in Mindanao, Philippines. Social Development Paper: Conflict Prevention and Reconstruction. Paper No.35. The World Bank.

Ritzer, George. 1996. Modern Sociological Theory. Fourth Ed. New York: Mc Graw-Hill.

Said, Zainal Abidin bin.M.. 2005. Migration and National Security: A Study of Indonesian Transients in Malaysia. Universiti Kebangsaan Malaysia. Bangi, Malaysia.

Sealza, Isaias S. 1992. Education and Adherence to Innovative Upland Farming Technological Package: Some Facets of Technology Transfer in the Integrated Social Forestry Program Sites, Bukidnon Province. Mindanao Polytechnic State College. Cagayan de Oro City.

Sealza, Isaias S. 2008. Human Welfare in Autonomous Region in Muslim Mindanao. Xavier University. Cagayan de Oro City.

Stets, Jan E. \& Burke, Peter J. 2003. A Sociological Approach to Self and Identity. Guildford Press. USA

Suhakam. Probe myKad Allegations. The Star August 24,2006

Tenaganita. 2005. Acting Today for Tomorrows Generation: Regional Conference on Stateless/Undocumented Children in Sabah, Malaysia.

The World Fact Book.2008. http://www.cia.gov/publications/factbook/geos/my.html.

Turner, Jonathan H. (1986). The Structure of Sociological Theory. The Dorsey Press. USA.

US Committee for Refugees and Immigrants-World Refugee Survey 2006 Country Report,

Webster's Encyclopedic Dictionary. 1961. New York: Lexicon Publications.

Zulueta, Francisco M. Nestor Edilberto B. Costales Jr. 2003. Methods of Research Thesis Writing and Applied Statistics. National Book Store. Manila. 